\section{Fatty Acid Profiling in Selected Cultivated Edible and Wild Medicinal Mushrooms in Southern United States}

\author{
D. A. Abugri ${ }^{1}$, W. H. McElhenney ${ }^{2}$ and K. R.Willian ${ }^{1,3^{*}}$ \\ ${ }^{1}$ Department of Chemistry, Department of Biology, College of Arts and Sciences, Tuskegee University, Tuskegee, AL, USA \\ ${ }^{2}$ Department of Agricultural and Environmental Sciences, College of Agriculture, Environment and Nutrition Sciences, Tuskegee University, Tuskegee, AL, 36088, USA \\ ${ }^{3}$ Department of Chemistry and Biochemistry, College of Sciences and Mathematics, Auburn University, Auburn, AL, 36849, USA
}

*Corresponding author: Dr. Kyle R. Willian, Department of Chemistry and Biochemistry, College of Sciences and Mathematics, Auburn University, Auburn, AL, 36849, USA, E-mail: krw0018@auburn.edu

Received date: December 18, 2015; Accepted date: February 11, 2016; Published date: February 17, 2016

Copyright: (2016 Abugri DA, et al. This is an open-access article distributed under the terms of the Creative Commons Attribution License, which permits unrestricted use, distribution, and reproduction in any medium, provided the original author and source are credited.

\begin{abstract}
The fatty acid composition was determined in the cultivated edible mushroom Agaricus bisporus (white), and the wild medicinal mushrooms, Turkey-tail (Trametes versicolor), Artist Conk (Ganoderma applanatum) and Tinder Polypore (Fomes fomentarius). The most prominent fatty acids present in all of the species studied were palmitic (C16: 0), stearic (C18: 0), oleic (C18: 1), and linoleic acid (C18: 2n6). The amount of linoleic acid in the cultivated species was $75.35 \pm 1.54 \%$; compared to $16.80 \pm 1.54$ to $30.30 \pm 1.54 \%$ in the wild medicinal mushrooms. Unsaturated fatty acids were the most abundant in both the cultivated edible and the wild medicinal mushrooms studied, which varied from $80.51 \pm 1.75 \%$ and $58.35 \pm 1.75$ to $69.61 \pm 1.75 \%$ respectively. The saturated fatty acid amounts ranged from $29.22 \pm 1.73$ to $41.65 \pm 1.73 \%$ in the wild mushrooms and $19.49 \pm 1.73 \%$ in the cultivated mushrooms. Oleic acid was the most abundant fatty acid in the wild mushrooms and varied from $20.66 \pm 0.87$ to $37.21 \pm 0.87 \%$. The $n-6: n-3$ ratios was $(28.45 \pm 7.38 \%$ in cultivated edible compared to $16.19 \pm 7.38$ to $55.42 \pm$ $9.03 \%$ in the wild medicinal mushrooms) generally higher than the recommended value of 2:1 or 3:1 in human diets.
\end{abstract}

Keywords: Wild edible; Medicinal mushroom; Cultivated; Agaricus bisporus; Fatty acid methyl esters; Omega 3 and 6

\section{Introduction}

Wild mushrooms are distributed worldwide, and consumption of both cultivated edible mushrooms and wild edible mushrooms has drawn much public interest due to their nutritional characteristics, medicinal properties and economic potential. The number of mushroom species estimated to exist is approximately 140,000 and of these only about 14,000 to 22,000 are characterized. This indicates that only about $10 \%$ to $15 \%$ have been well-characterized [1,2]. Supposing that mushrooms of nutritional and medicinal usefulness among those unidentified and uncharacterized constitute only $5 \%$, this implies that about 7000 undiscovered species could be beneficial to humans $[1,2]$.

In many countries mushrooms serve as a natural food resource because of their high nutritional, medicinal and economic value [2-4]. Fungus collecting in certain parts of the world is often seen as a hobby but several studies have illustrated that mushrooms are an essential source of nutrients and pharmaceutical raw materials, and therefore are a source of income generation in both developed and underdeveloped nations $[4,5]$.

More recently, attention has been focused on both cultivated and wild mushrooms to exploit the nutritional and medicinal applications in regard to improving health. Studies in Africa [6], Italy [7], U.S [8], India [9], Canada [10], Russia [11], France [12], Japan [13] and Pakistan [14] have investigated this issue further.

The nutritional and medicinal compositions in mushrooms are well documented. For instance, some mushrooms (e.g. Agaricus bisporus [15,16] and Tricholoma matsutake [17], have been appreciated because of their therapeutic activity such as, reduction of hypercholesterolemia, antherosclerosis, hypertension and immune therapy in cancer $[2,18,19]$. Clinical studies have also documented that some mushrooms have medicinal potential in lowering serum cholesterol levels (Tricholoma matsutake, G. applanatum, Trametes Versicolor, Fomes fomentanus), can act as antitumor and antiviral agents (Trametes Versicolor, Fomes fomentaus), and have antithrombotic and immunomodulating effects (Tricholoma matsutake, Trametes Versicolor) [2,15,19-21]. The ability of mushrooms to exert hypocholesterolemic effects have been reported in rats [22-26]. Wild mushrooms have demonstrated some pharmacological characteristics such as antitumor $[20,22]$.

It is, therefore, vital to study the fatty acid and other chemical composition of mushrooms in southern US to document their chemical profile(s) as a preliminary means to further study their biochemical and physiological implications to human health.

In recent studies, unsaturated fatty acids (UFs), particularly polyunsaturated fatty acids (PUFAs), have been reported in many wild mushrooms and are believed to have important contributions in nutritional and medicinal application [15,27]. Linoleic (LA) and $\alpha-$ linolenic (ALA) acids are essential fatty acids that are fundamental in human nutrition and serve as important precursors for the biosynthesis of other long chain fatty acids [28]. In most studies conducted in fungi, n-3 content and n- 6 to n-3 ratios have not been given much attention. However, the n-3 levels and its ratio factor with the n-6 FAs may be a crucial factor in the reduction of cardiovascular, inflammatory, immunomodulating and cancer diseases. In this perspective, determination of fatty acid profile(s) and n-6 to n-3 ratios in cultivated and wild medicinal mushrooms will aid consumers in 
selecting dietary components that offer better nutritional balance and good health functional compounds.

Although, mycological studies have reported the fatty acid profiles and other essential nutrients of cultivated edible and some wild medicinal mushrooms from some regions in the United States, there is limited information regarding the fatty acid composition and lipid health biomarkers of wild medicinal mushrooms located in the Southern region of the United States. These mushrooms were selected based on their abundance in the county and previous biological activity claims reported in other countries $[2,15,19,20]$. Hence, the present study was conducted to compare the fatty acid compositions, n6: $\mathrm{n} 3$ ratio and fatty acid biomarkers of wild medicinal mushrooms species in this region and compare them to well characterized cultivated edible mushroom (Agaricus bisporus).

\section{Materials and Methods}

\section{Sample collection}

In this study four mushrooms were sampled; one (1) cultivated edible mushroom Agaricus bisporus (white) was purchased from a local supermarket in Tuskegee, AL, USA, and three (3) wild medicinal mushrooms were collected from tree logs on the campus of Tuskegee University in Tuskegee, in Macon County of Alabama, USA between spring and summer session (May and August, 2009). Soil pH, pressure, nutrients, moisture content, ions and electrical conductivity were not measured because there was no information regarding these conditions stated in the cultivated mushrooms species purchased. All samples were washed thoroughly with deionized water and immediately put into jars and stored under nitrogen at $-20^{\circ} \mathrm{C}$ for later analyses.

\section{Fatty Acid Methyl Ester synthesis}

A modified procedure [29] was adopted for the analysis. Ten grams $(10.0 \mathrm{~g})$ of mushroom was weighed and placed into a $16 \times 125 \mathrm{~mm}$ screw-cap Pyrex culture tube. Forty microliters $(40 \mu \mathrm{l})$ of a C19: 0 internal standard (IS) (1, 2 Dinonadecanoyl-syn-glycero-3phosphocholine, came from Avanti Polar Lipids Inc) of concentration $0.5 \mathrm{mg} / \mathrm{ml}$, followed by $0.7 \mathrm{ml}$ of $5 \mathrm{M} \mathrm{KOH}$ (ACS grade) in water, and $5.3 \mathrm{ml}$ of $\mathrm{MeOH}$ (HPLC grade, Fisher Scientific) were added to the culture tube and the mixture incubated for $90 \mathrm{~min}$ at $55^{\circ} \mathrm{C}$ in water bath vigorously shaking to ensure total hydrolysis of samples. Following the incubation period, the mixture was cooled for $5 \mathrm{~min}$ in an ice bath and $0.58 \mathrm{ml}$ of $24 \mathrm{~N} \mathrm{H}_{2} \mathrm{SO}_{4}$ in water was added. Tubes were inverted several times-mixed properly to breakdown the presence of $\mathrm{K}_{2} \mathrm{SO}_{4}$ precipitate formed after the addition of the acid and reincubated as indicated above to generate fatty acid methyl esters (FAMEs). After FAME synthesis, tubes were cooled in ice bath for 5 min, $3 \mathrm{ml}$ of hexane was added, then vortex-mixed for $5 \mathrm{~min}$, then centrifuged for 5 min using a clinical tabletop centrifuge (IEC Centra CL 2). The organic phases containing the FAMEs were filtered using a $0.2 \mu \mathrm{m}$ PTFE filter into gas chromatography (GC) vials. Vials were capped and stored at $-20^{\circ} \mathrm{C}$ until GC analysis.

\section{Gas chromatography (GC) separation and quantitation of individual fatty acids}

An Agilent GLC 6890N equipped with a flame ionization detector (FID) was used for the separation and quantification of fatty acids methyl esters (FAMEs). Samples were injected into the column via a split injector. The split ratio was 5:1. Separations were done using a DB23 capillary column (Model No.122-2362, $60.0 \mu \mathrm{m} \times 250 \mu \mathrm{m} \times 0.25$ $\mu \mathrm{m}, \mathrm{J}$ and $\mathrm{W}$ Scientific). The initial oven temperature was maintained at $130^{\circ} \mathrm{C}$, held for $1 \mathrm{~min}$, subsequently increased to $170^{\circ} \mathrm{C}$ at a rate of $6.50^{\circ} \mathrm{C} / \mathrm{min}$, then moved to $215^{\circ} \mathrm{C}$ and held for $12 \mathrm{~min}$ at a rate of $2.75^{\circ} \mathrm{C} / \mathrm{min}$ then increased to $230^{\circ} \mathrm{C}$ at $40^{\circ} \mathrm{C} / \mathrm{min}$. Helium was used as a carrier gas at a flow rate of $2.6 \mathrm{ml} / \mathrm{min}$ with average velocity $40 \mathrm{~cm} /$ sec, and the column head pressure was set at $48.27 \mathrm{kpa}$. Both injector and detectors were set at $250^{\circ} \mathrm{C}$. Fatty acid methyl esters were identified by comparison with 54 fatty acid methyl esters standard GLC463 (obtained from Nu-Chek Prep Inc., Elysian, Minnesota) retention times. Fatty acids were also reported in percentage of total identified peaks.

The degree of unsaturation of $\mathrm{C} 18 \mathrm{FA}(\Delta / \mathrm{mol} \mathrm{C} 18)$ was estimated using the relationship; $\Delta / \mathrm{mol} \mathrm{C} 18=[(1 \times 18: 1)+(2 \times 18: 2)+(3 \times$ $18: 3)] / \Sigma(\mathrm{C} 18$ FA) [30] as indicators for nutritional, medicinal, taxonomical and technological applications.

\section{Statistical analysis}

Data for this study were analyzed using a one-way analysis of variance. When differences among mushrooms were detected at $\mathrm{p}<0.05$, Fisher's LSD was used to compare means. Results are reported as means in $\%$ total of fatty acids identified.

\section{Results}

This study identified 31 individual fatty acids in each mushroom species that are presented as the \% of total FA identified in the cultivated edible and wild medicinal mushrooms (Table 1).

Fatty acids observed at greater than $2 \%$ in at least one species were C10:0, C16:0, C16:1, C18:0, C18:1, C18:2n6, C18:3n3, C22:4n6, $\mathrm{C} 22: 6 \mathrm{n} 3$ and $\mathrm{C} 22: 5 \mathrm{n} 3$ in the two classes studied shown in table 1. An important notable difference between species was that in the cultivated species C16:1, C17:0, C17:1, C18:1, C18:1t and C18:3n3 were not detected, whereas for most of the wild medicinal mushrooms species these FAs were observed, except for Tinder polypore and Artist conk where $\mathrm{C} 18: 3 \mathrm{n} 3$ was absent and C18:1t was not detected in the Turkeytail mushrooms. The C16:0 and C18:0 levels were higher in only Turkey-tail and Artist Conk of the wild medicinal mushrooms than the cultivated species.

The monounsaturated fatty acid (C18: 1) was absent in the cultivated species, whereas in the wild medicinal mushrooms, it constituted $20.66 \pm 0.87 \%$ to $37.21 \pm 0.87 \%$ of the total fatty acids identified. In the cultivated mushrooms (Agaricus bisporus white) the dominant fatty acid was linoleic acid (C18:2n6) with $75.35 \pm 1.54 \%$, whereas in the wild medicinal mushrooms oleic acid (C18:1) with $20.66 \pm 0.87 \%$ (Turkey-tail), $32.21 \pm 0.87 \%$ (Artist conk) and $37.21 \pm$ $0.87 \%$ (Tinder polypore) was most prevalent. This percent is very important because oleic acid play crucial roles in the biochemical and physiological pathways in cells accumulation of cholesterol in the human body. This conjecture is supported by Grundy, [31] that Oleic acid (C18:1) can lower serum cholesterol concentrations because it acts as a good substrate for liver enzyme which converts cholesterol deposits into an inactive form known as Acyl CoA transferase:cholesterol acyltransferase. The richest amounts of oleic acid are in olive, canola and peanut oils and even some beef [32]. 
Citation: Abugri DA, McElhenney WH, Willian KR (2016) Fatty Acid Profiling in Selected Cultivated Edible and Wild Medicinal Mushrooms in

Page 3 of 7

\begin{tabular}{|c|c|c|c|c|}
\hline$\% F A$ & Turkey tail & $\begin{array}{l}\text { Tinder } \\
\text { polypore }\end{array}$ & Artist conk & $\begin{array}{l}\text { Agaricus } \\
\text { bisporus } \\
\text { (white) }\end{array}$ \\
\hline C8:0 & - & - & - & $0.35 \pm 0.18^{a}$ \\
\hline C9:0 & $0.99 \pm 0.18^{b}$ & $1.77 \pm 0.18^{a}$ & $1.83 \pm 0.18^{a}$ & $0.40 \pm 0.22^{b}$ \\
\hline C10:0 & $1.75 \pm 0.44^{b}$ & $3.16 \pm 0.44^{b}$ & $6.00 \pm 0.44^{a}$ & $0.51 \pm 0.54^{c}$ \\
\hline C13:0 & $1.06 \pm 0.10^{a}$ & - & - & - \\
\hline C13:1 & - & $0.56 \pm 0.03^{a}$ & - & - \\
\hline C14:0 & $1.59 \pm 0.13^{a}$ & - & $0.89 \pm 0.13^{b}$ & - \\
\hline C14:1 & $0.96 \pm 0.21^{a}$ & $0.58 \pm 0.21^{a}$ & - & $0.39 \pm 0.21^{a}$ \\
\hline C15:0 & $1.74 \pm 0.27^{a}$ & - & $0.83 \pm 0.27^{b}$ & $0.65 \pm 0.27^{b}$ \\
\hline C15:1 & - & $0.61 \pm 0.004^{a}$ & - & $0.35 \pm 0.004^{b}$ \\
\hline C16:0 & $20.27 \pm 0.95^{a}$ & $15.87 \pm 0.95^{b}$ & $\begin{array}{l}20.22 \\
0.95^{\mathrm{a}}\end{array}$ & $12.90 \pm 0.95^{b}$ \\
\hline C16:1 & $3.07 \pm 0.10^{a}$ & $1.43 \pm 0.10^{b}$ & $1.61 \pm 0.10^{b}$ & - \\
\hline C16:1t & $1.65 \pm 0.32^{\mathrm{a}}$ & $0.79 \pm 0.39^{a}$ & $1.06 \pm 0.32^{\mathrm{a}}$ & $0.96 \pm 0.32^{\mathrm{a}}$ \\
\hline C17:0 & $0.72 \pm 0.10^{b}$ & $0.71 \pm 0.10^{b}$ & $1.10 \pm 0.10^{a}$ & - \\
\hline C17:1 & $3.00 \pm 0.19^{a}$ & $1.58 . \pm 0.19^{b}$ & $1.61 \pm 0.19^{b}$ & - \\
\hline C18:0 & $6.76 \pm 0.27^{c}$ & $5.91 \pm 0.27^{c}$ & $\begin{array}{l}10.78 \\
0.27^{\mathrm{a}}\end{array}$ & $3.70 \pm 0.27^{b}$ \\
\hline C18:1 & $20.66 \pm 0.87^{c}$ & $37.21 \pm 0.87^{a}$ & $\begin{array}{l}32.00 \\
0.87^{\mathrm{b}}\end{array}$ & - \\
\hline $\mathrm{C} 18: 1 \mathrm{t}$ & - & $1.86 \pm 0.11^{\mathrm{a}}$ & $1.09 \pm 0.14^{b}$ & - \\
\hline $\mathrm{C} 18: 1 \mathrm{n} 7$ & $2.07 \pm 0.25^{\mathrm{a}}$ & $0.72 \pm 0.25^{b}$ & - & $0.89 \pm 0.25^{b}$ \\
\hline C18:2n6 & $30.30 \pm 1.54^{a}$ & $23.86 \pm 1.54^{b}$ & $\begin{array}{l}16.80 \\
1.54^{\mathrm{c}}\end{array}$ & $75.35 \pm 1.54^{d}$ \\
\hline C18:3n3 & $3.42 \pm 0.58^{\mathrm{a}}$ & - & - & - \\
\hline C20:0 & - & $1.42 \pm 0.13^{a}$ & - & $1.29 \pm 0.13^{a}$ \\
\hline $\mathrm{C} 20: 2 \mathrm{n} 6$ & - & - & - & - \\
\hline C20:3n6 & - & - & - & - \\
\hline $\mathrm{C} 20: 4 \mathrm{n} 6$ & - & - & $5.40 \pm 0.35^{a}$ & - \\
\hline $\mathrm{C} 20: 5 \mathrm{n} 3$ & - & - & - & $1.21 \pm 0.27^{a}$ \\
\hline $\mathrm{C} 22: 2 \mathrm{n} 6$ & - & - & $1.43 \pm 0.11^{b}$ & - \\
\hline $\mathrm{C} 22: 4 \mathrm{n} 6$ & - & - & - & - \\
\hline C24:0 & - & $0.58 \pm 0.06^{a}$ & - & - \\
\hline C22:5n3 & - & - & - & - \\
\hline C22:6n3 & - & $0.45 \pm 0.43^{a}$ & - & $2.24 \pm 0.43^{b}$ \\
\hline C24:1 & - & $0.55 \pm 0.07^{a}$ & - & - \\
\hline
\end{tabular}

means plus standard errors with triplicate determination $(n=3)$, Means sharing the same superscript across rows are not significantly different at $\mathrm{p}<0.05$. - not detected.

The $\mathrm{C} 22: 5 \mathrm{n} 3$ and $\mathrm{C} 22: 6 \mathrm{n} 3$ were found in the cultivated edible mushrooms with DHA content around $2.24 \pm 0.43 \%$. Conversely, in the wild medicinal mushroom DHA was present only in the Tinder polypore species in a small amount $(0.45 \pm 0.43 \%)$.

The results for total unsaturated fatty acids (UFA), total saturated fatty acids (SFA), monounsaturated fatty acids (MUFA), polyunsaturated fatty acids (PUFA), n-6, n-3, MUFA:SFA, PUFA:SFA, UFA:SFA, linoleic to oleic ratio (L:O), n-6:n-3 and the degree of unsaturation of $\mathrm{C} 18(\Delta / \mathrm{mol} \mathrm{C} 18)$ were calculated as indicators for nutritional, medicinal and technological purposes are shown in table 2. The study depicted an interesting trend with respect to the PUFA and MUFA content within the wild medicinal mushrooms and between the cultivated edible mushrooms. It was observed that the MUFA content in the wild medicinal mushrooms accounted for $45.44 \pm 0.86 \%$ in (Tinder polypore), $37.00 \pm 0.86 \%$ in (Artist conk), and $31.41 \pm 0.86 \%$ in (Turkey-tail), whereas in the cultivated species (Agaricus bisporus white) constituted $2.47 \pm 0.86 \%$. The PUFA amounts in the wild medicinal mushrooms were in order of highest to lowest Turkey-tail $>$ Tinder polypore $>$ Artist conk. The PUFA was substantially higher $(\mathrm{p}<.05)$ in the Turkey-tail compared to the rest of the wild medicinal mushroom.

\begin{tabular}{|c|c|c|c|c|}
\hline Ratios & Turkey tail & $\begin{array}{l}\text { Tinder } \\
\text { polypore }\end{array}$ & $\begin{array}{l}\text { Artist } \\
\text { conk }\end{array}$ & $\begin{array}{l}\text { Agaricus } \\
\text { bisporus } \\
\text { (white) }\end{array}$ \\
\hline MUFA & $\begin{array}{ll}31.41 & \pm \\
0.86^{\mathrm{a}} & \end{array}$ & $45.44 \pm 0.86^{b}$ & $\begin{array}{ll}37.00 & \pm \\
0.86^{c} & \end{array}$ & $2.47 \pm 0.86^{d}$ \\
\hline PUFA & $\begin{array}{l}33.72 \\
1.76^{\mathrm{b}}\end{array}$ & $24.16 \pm 1.76^{c}$ & $\begin{array}{l}21.34 \\
1.76^{\mathrm{c}}\end{array}$ & $78.04 \pm 1.76^{a}$ \\
\hline SFA & $\begin{array}{ll}34.88 & \pm \\
1.73^{\mathrm{b}} & \end{array}$ & $29.22 \pm 1.73^{\mathrm{c}}$ & $\begin{array}{ll}41.65 & \pm \\
1.73^{\mathrm{a}} & \end{array}$ & $19.49 \pm 1.73^{d}$ \\
\hline UFA & $\begin{array}{ll}65.13 \\
1.75^{\mathrm{b}}\end{array}$ & $69.61 \pm 1.75^{\mathrm{b}}$ & $\begin{array}{ll}58.35 & \pm \\
1.75^{\mathrm{c}} & \end{array}$ & $80.51 \pm 1.75^{a}$ \\
\hline MUFA/SFA & $0.92 \pm 0.06^{b}$ & $1.56 \pm 0.06^{a}$ & $\begin{array}{ll}0.89 & \pm \\
0.06^{b} & \end{array}$ & $0.13 \pm 0.06^{c}$ \\
\hline PUFA/SFA & $0.99 \pm 0.20^{b}$ & $0.83 \pm 0.20^{\mathrm{b}}$ & $\begin{array}{ll}0.52 & \pm \\
0.20^{\mathrm{b}} & \end{array}$ & $4.02 \pm 0.20^{\mathrm{a}}$ \\
\hline UFA/SFA & $\begin{array}{l}1.91 \\
0.22^{\mathrm{bc}}\end{array}$ & $2.38 \pm 0.22^{b}$ & $\begin{array}{ll}1.41 & \pm \\
0.22^{\mathrm{c}} & \end{array}$ & $4.14 \pm 0.22^{\mathrm{a}}$ \\
\hline$n-3$ & $3.42 \pm 1.22^{c}$ & $0.30 \pm 1.22^{b}$ & nd & $2.70 \pm 1.21^{c}$ \\
\hline$n-6$ & $\begin{array}{l}30.30 \\
1.77^{\mathrm{a}}\end{array}$ & $23.86 \pm 1.77^{d}$ & $\begin{array}{ll}21.34 & \pm \\
1.77^{d} & \end{array}$ & $75.35 \pm 1.77^{b}$ \\
\hline$n-6 / n-3$ & $\begin{array}{ll}16.19 & \pm \\
7.38^{\mathrm{b}} & \end{array}$ & $55.42 \pm 9.03^{a}$ & nd & $28.45 \pm 7.38^{b}$ \\
\hline Linoleic/Oleic & $1.48 \pm 0.08^{\mathrm{a}}$ & $0.64 \pm 0.08^{b}$ & $\begin{array}{ll}0.53 & \pm \\
0.08^{b} & \end{array}$ & nd \\
\hline$\Delta / \mathrm{mol} \mathrm{C} 18$ & $1.15 \pm 0.03^{b}$ & $0.72 \pm 0.03^{c}$ & $\begin{array}{ll}0.57 & \pm \\
0.03^{\mathrm{d}} & \end{array}$ & $1.89 \pm 0.03^{a}$ \\
\hline
\end{tabular}

Table 1: Fatty acids composition (\% of total FAs) of cultivated edible (Agaricus bisporus white) and wild medicinal mushrooms (Turkeytail, Tinder polypore, and Artist conk) in Southern Region of the United States using direct FAMEs synthesis. Values are least significant

Table 2: Percentage ratio of MUFA, PUFA \& SFA, n 6 and n3, $\Delta /$ mol C18 and Linoleic and Oleic acid of cultivated edible and wild medicinal mushrooms $(n=3)$. PUFA-Polyunsaturated fatty acids, SFA- 
Saturated fatty acids, n-3 and n-6-Omega $3 \& 6$ polyunsaturated fatty acids, and not determined , $\Delta / \mathrm{mol} \mathrm{C18-degree} \mathrm{of} \mathrm{unsaturation} \mathrm{of} \mathrm{C} 18$ FAs. Mean values on the same row followed by a same letter not significantly different according to least significant (LS) means (at $\mathrm{p}<0.05$ ). Values are reported as least significant means plus standard error (LSMean $\pm \mathrm{SE}$ ) of triplicate determination.

The MUFA and UFA: SFA varied significantly among the wild medicinal mushroom at $\mathrm{p}<0.05$. The SFA content was greater in the wild medicinal mushrooms than the cultivated species. The MUFA: SFA were observed to differ only in the Tinder Polypore out of the three wild medicinal mushrooms considered, and is lower in the Agaricus bisporus (white) considered for the study. Another interesting observation was that the total fatty acids identified were basically full of $n-6$ constituting about $21.34 \%$ to $75.35 \%$, whereas the $n-3$ only made up of $0.30 \%$ to $3.42 \%$. The $\mathrm{n} 6 / \mathrm{n} 3$ ratio ranged between 55.42 with a statistically difference in only Tinder polypore medicinal mushrooms. The linoleic: oleic ratio differs only in the Turkey-Tail mushroom compared to other wild medicinal mushrooms. The $\Delta / \mathrm{mol}$ C18 were significant different in the wild medicinal species, whereas in the cultivated edible type no differences were detected.

There was only one slight significant variation in MUFA, SFA, UFA and MUFA: SFA with one of the wild medicinal mushroom (i.e. Tinder polypore) compared to all of the other species. For the ratio of UFA: SFA variation was observed in the Turkey-tail and the Artist conk species compared to the other species. There were no differences between inter-species in terms of the ratios of PUFA: SFA in the cultivated species, as well as that of the wild medicinal mushrooms at the $\mathrm{p}<0.05$. However, differences were detected between the cultivated species and the wild mushrooms. The degree of unsaturation $(\Delta / \mathrm{mol}$ C18) in the wild medicinal mushrooms differs from the cultivated edible species (Table 2).

\section{Discussion}

The identified fatty acids in these analyses of the cultivated edible species (Agaricus bisporus) ranged from (C8:0 to C24:1) which agreed with what has been reported in most cultivated species, and (C9:0 to C24:1) in the wild medicinal mushrooms [33-37].

The most abundant fatty acids identified were C16:0, C18:0, C18:1 and $\mathrm{C} 18: 2 \mathrm{n} 6$ and the rest in smaller amounts in cultivated categories of mushrooms. This was in agreement with what has been reported in Agaricus bisporus sp [12,36,38,39] and some wild edible mushrooms (Table 2) $[30,36,39,40]$.

\begin{tabular}{|c|c|c|c|c|c|c|c|c|c|c|c|}
\hline \multirow{2}{*}{ Fatty Acid } & \multirow{2}{*}{$\begin{array}{l}\text { Agaricu } \\
s \\
\text { bisporu } \\
s^{\star} a\end{array}$} & \multirow{2}{*}{$\begin{array}{l}\text { L. } \\
\text { deliciosus } \\
\text { a }\end{array}$} & \multirow{2}{*}{$\begin{array}{l}\text { Lentinus } \\
\begin{array}{l}\text { sajor- } \\
\text { cajub }\end{array}\end{array}$} & \multirow{2}{*}{$\begin{array}{l}\text { Lactarius } \\
\text { deliciosus } \\
\text { b }\end{array}$} & \multirow{2}{*}{$\begin{array}{l}\text { Macrolepi } \\
\text { ota } \\
\text { procerab }\end{array}$} & \multirow{2}{*}{$\begin{array}{l}\text { Ganoderma } \\
\text { applanatumc }\end{array}$} & \multirow{2}{*}{$\begin{array}{l}\text { Suillus } \\
\text { grevilleic* }\end{array}$} & \multirow{2}{*}{$\begin{array}{l}\text { Schizophyllu } \\
\text { m communed }\end{array}$} & $\begin{array}{l}\text { Lentinue } \\
s\end{array}$ & $T$. & A. \\
\hline & & & & & & & & & edodesd & texensee & $\begin{array}{l}\text { bisporus } \\
\neq\end{array}$ \\
\hline C16:0 & 4.34 & 12.08 & 15.4 & 16.3 & 4.6 & 18.3 & 8.9 & 20.8 & 19.2 & 11.4 & 15.1 \\
\hline C16:1 & - & 0.92 & 0.1 & 0.9 & - & - & 1.01 & - & - & - & Trace \\
\hline C18:0 & 1.79 & 25.33 & - & 6.1 & - & 3.31 & 1.49 & 2.5 & 2.7 & 3.4 & 15.6 \\
\hline C18:1 & 21.47 & 41.26 & 23.5 & 33 & 17.2 & 22.5 & 43.9 & 10.4 & 8.3 & 45.9 & 13.6 \\
\hline C18:2n6 & 44.19 & 17.06 & 54.9 & 37.1 & 47 & 28.8 & 40.1 & 61.3 & 68.8 & 38 & 55.1 \\
\hline C18:3n3 & - & 0.26 & - & - & 15.6 & 0.4 & 0.63 & 4.8 & 0.6 & - & Trace \\
\hline C18:3n6 & - & - & - & - & - & - & - & - & - & - & - \\
\hline $\mathrm{C} 20: 0$ & - & 0.44 & - & - & 5.6 & 0.26 & 0.18 & 0.2 & 0.4 & $<0.2$ & - \\
\hline SFA & 6.13 & 37.85 & 15.4 & 22.4 & 10.2 & 21.87 & 10.57 & 23.5 & 22.3 & 14.4 & 30.7 \\
\hline UFA & 65.66 & 59.5 & 78.5 & 71 & 79.8 & 51.7 & 85.64 & 76.5 & 77.7 & 83.9 & 68.7 \\
\hline UFA:SFA & 10.71 & 1.57 & 5.09 & 3.17 & 7.82 & 2.36 & 8.1 & 3.26 & 3.48 & 5.83 & 4.05 \\
\hline L/O & 2.06 & 0.41 & 2.34 & 1.12 & 2.73 & 1.28 & 0.91 & 5.89 & 8.29 & 0.83 & 2.24 \\
\hline
\end{tabular}

Table 3: Some common fatty acids composition (\%) of selected cultivated edible and wild mushrooms in Portugala, Pakistana ${ }^{*}$ Indiabd, Canadacc $^{*}$ and USef. Source: ${ }^{\star}$ a- Sadiq et al., 2008 Iran.J.Chem.Chem.Eng. a-Barros et al., 2007 Food Chemistry, b-Kavishree et al., 2008. Food Chemistry c- Pedneault et al., 2006 and $2008^{*}$ mycological Research. d-Longvah \& Deosthale, 1998. Food Chemistry, e-Beuchat et al., 1993, Food Chemistry.ł- Holtz et al., 1972 .Plant physiology. and e are from U.S.A.

The chief unsaturated fatty acid was linoleic acid which constituted $75.35 \%$ of the total fatty acids identified for all the cultivated edible species. These results are in agreement with previous literature on Agaricus bisporus FAs reported by Hughes, (1962) to range between $63 \%$ to $74 \%, 68.4 \%$ in [35], $66 \%$ to $79 \%$ in [12] and $53 \%$ to $79 \%$ by [39].
However, the linoleic acid level in this study was higher than other values in literature of $55.1 \%$ [38], 44.19\% [41] and absent or not detected [37]. These differences may be attributed to methodological, geographical, instrumental and environmental factors.

The UFA content ranged from $58.35 \%$ to $69.61 \%$ and $80.51 \%$ in the wild medicinal mushrooms and the cultivated edible mushrooms 
respectively, which is in line with previously reported data on Agaricus bisporus [27,39] and some wild edible mushrooms [30,37,40-43].

The (\%) FAs range reported in this study, in the cultivated Agaricus bisporus brown and white brand agrees with previous studies $[12,27,32,34-36,39]$. However, in the wild medicinal mushroom, the trend was different with oleic acid showing as the dominant unsaturated fatty ranging from $20.66 \%$ to $37.21 \%$ (Table 1 ). These results suggest that predominance of individual fatty acids varies from species to species although they could belong to same phylum and family.

In general FAs significantly varied between the cultivated edible and the wild medicinal mushrooms. This may be attributed to the intrinsic nature of some mushroom species in the production of greater amounts of some unique FAs compared to others species within the environment [37]. In addition, the trend could possibly be ascribed by the geographical location of the fungus, soil $\mathrm{pH}$, pressure, nutrients, moisture content, ions and chemical interaction between the host, age of the mushrooms, enzymatic activities in the mushroom itself and its symbiotic agents (like insects). This is supported by previous studies [44-46] that FAs composition in most eukaryotic microorganisms tends to be influenced by environment factors, like $\mathrm{pH}$, temperature, aeration, enzymatic activities and media component. However, since this current study did not include data from environmental parameters (soil $\mathrm{pH}$, Moisture, humidity, conductivity), caution must be exercised when interpreting these factors with this current study.

The n-6, n-3 and their ratios have not been given much attention in previous fungi fatty acid studies, although, they contribute greatly to human nutrition and health. In general, the wild medicinal and cultivated edible mushrooms species were higher in n-6 than n-3. These trends may attribute to the high linoleic acid amounts in the mushrooms studied.

The ratio of n-6: $n-3$ is higher than the 15:1 ratio reported in the typical western diet by Simopoulos, (2002), and also the 10:1 ratio in the typical American diet [47-49]. The ratio of n-6: n-3 was also well above the recommended values of $3: 1$ or $2: 1$ [50-52]. This unfavorable n-6: n-3 ratio, should not be viewed, however, to detract from the overall healthful benefits of consuming mushrooms. The total amount of fat in mushroom is very low about $1 \mathrm{mg} / \mathrm{g}$ for every $100 \mathrm{~g}$ of servicing cup, and therefore consuming a regular serving of mushrooms would only add (about $1 \mathrm{mg}$ ) of n-6: n-3 fatty acid. The high ratio is not necessarily a health detriment.

The ratio of PUFA:SFA and linoleic:oleic were in agreement with previous literature in some edible wild fungus, such as T. claveryi, $P$. juniperi [53] and Agaricus arvensis and G. applanatum [30].

The linoleic:oleic ratio was similar to those obtained in T. claveryi and P. juniperi [53], in G. arinarius, Boletus edulis, and Helvella crispa [43] in some edible mushrooms. The UFA: SFA ratio in both the wild medicinal and the cultivated edible mushrooms were similar to what was reported in studies of T. claveryi, and P. juniperi; G. arinarius, Boletus edulis, and Helvella crispa [43]; Agaricus arvensis, and G.applanatum [30]; Agaricus bisporus [39]. However, the ratios were lower than what was reported in some Basidiomycota, in the family Boletaceae e.g. Boletus edulis, Boletus erythropus, and Boletus variipes [37].

Some of the fatty acids detected are considered as bio-indicators for soil fungi characterization in the environment [48]. For instance, the linoleic acid (18:2n6) content in the various mushrooms can be used as an indicator for the determination of the number of fungi and its biomass content in soils [48].

The linoleic acid to oleic acid ratio and some of the identified unsaturated FAs such as; C16:1, C16:1t, C18:1, C18:1n7, C18:1n9t, and C18:2n6 may be useful as biomarkers for physiological, taxonomical and cell differentiation studies in two similar or different species of mushrooms, plants, algae and bacteria within the same family [48,54-60].

The degree of unsaturation for C18 FA $(\Delta / \mathrm{mol} \mathrm{C18})$ in the cultivated species (Agaricus bisporus, white) was 1.89 . With regards to the wild medicinal mushrooms C18 FA $(\Delta / \mathrm{mol} \mathrm{C18})$ of unsaturation varied from $0.57 \pm 0.03$ to $1.15 \pm 0.03 \%$. The $\Delta / \mathrm{mol} \mathrm{C18}$ results were similar to what has been reported in higher Basidiomycetes indigenous mushrooms in eastern Canada [30]. This may be used as indicators for nutritional, medicinal, and taxonomical purposes.

\section{Conclusion}

In summary, the studies have determined the fatty acid composition of selected wild medicinal mushrooms (Turkey-tail, Tinder polypore and Artist conk) in the Southern region of United States. The fatty acid compositions vary considerable among these wild medicinal mushrooms and the cultivated edible species Agaricus bisporus. Both wild medicinal mushrooms and cultivated edible mushrooms had high unsaturated fatty acids than saturated fatty acids. The wild mushrooms had mainly lower linoleic acid content ( $1 / 2$ to $1 / 5$ of the cultivated species). In all species the $n-6 / n-3$ ratios were higher than the recommended ratio 3:1 but not substantially different from many common vegetable products. The fatty acid health biomarkers were within the values reported in some wild and cultivated edible mushrooms in literature.

Hence, nutritional, medicinal and economic studies should be encouraged into cultivated edible and wild mushrooms in the Southern region of United States because few studies have been conducted that evaluate and characterize mushrooms for their potential usefulness.

\section{Acknowledgment}

This work was carried out with the funds of Sustainable Agriculture Research and Education grant (SARE) with grant number: 09AGR-367947-TU from the College of Agricultural, Environmental and Natural Sciences. We also expressed our gratitude to Dr. Melissa S. Reeves from the Department of Chemistry, Tuskegee University, Alabama for her contribution in diverse ways for the success of the study, and also to Dr. David W. Fischer a mycologist from University of Texas who assisted in the identification of the mushrooms for the study.

\section{References}

1. Hawksoworth DL (2001) Mushrooms: the extent of the unexplored potential. International Journal for Medicinal Mushrooms 3: 333-7.

2. Lindequist U, Niedermeyer TH, Jülich WD (2005) The pharmacological potential of mushrooms. Evid Based Complement Alternat Med 2: 285-299.

3. de Román M, Boa E, Woodward S (2006) Wild-gathered fungi for health and rural livelihoods. Proc Nutr Soc 65: 190-197. 
4. Boa E (2004) Wild Edible Fungi. A Global Overview of Their Use and Importance to People. Non-wooded Forest Products Series No.17. Rome: FAO.

5. Oso BA (1975) Mushrooms and the Yoruba people of Nigeria. Mycologia 67: 311-319.

6. Aletor VA (1995) Compositional studies on edible tropical species of mushrooms. Food Chemistry 54: 265-268.

7. Senatore F (1990) Fatty acid and free amino acid content of some mushrooms. Journal of Science Food Agriculture 51: 91-96.

8. Beuchat LR, Brenneman TB, Dove CR (1993) Composition of the pecan truffle (Tuber texense). Food Chemistry 46: 189-192.

9. Longvah T, Deosthale YG (1998) Compositional and nutritional studies on edible wild mushroom from northeast India. Food Chemistry 65 331-334.

10. Pedneault K, Angers P, Gosselin A, Tweddell RJ (2008) Fatty acid profiles of polar and neutral lipids of ten species of higher basidiomycetes indigenous to eastern Canada. Mycol Res 112: 1428-1434.

11. Dembitsky VM, Shubina EE, Kashin AG (1992) Phospholipid and fatty acid composition of some basidiomycetes. Phytochemistry 31: 845-849.

12. Cruz C, Suberville CN, Montury M (1997) Fatty Acid Content and Flavor Compound Release in Two Strains of Agaricus bisporus, According to Three Stages of Development. J Agric Food Chem 45: 64-67.

13. Amakura $\mathrm{Y}$, Kondo K, Akiyama H, Ito H, Hatano T, et al. (2006) Characteristic long-chain fatty acid of Pleurocybella porrigens. See comment in PubMed Commons below Shokuhin Eiseigaku Zasshi 47: 178-181.

14. Saidiq S, Bhatti HN, Muhammad AH (2008) Studies on Chemical composition and nutritive evaluation of wild edible mushrooms. Iran J Chem Chem Eng 27: 151-154.

15. Chen S, Oh SR, Phung S, Hur G, Ye JJ, et al. (2006) Anti-aromatase activity of phytochemicals in white button mushrooms (Agaricus bisporus). See comment in PubMed Commons below Cancer Res 66: 12026-12034.

16. Jeong SC, Jeong YT, Yang BK, Islam R, Koyyalamudi SR, et al. (2010) White button mushroom (Agaricus bisporus) lowers blood glucose and cholesterol levels in diabetic and hypercholesterolemic rats. Nutr Res 49-56.

17. Hoshi H, Yagi $Y$, Iijima H, Matsunaga K, Ishihara $Y$, et al. (2005) Isolation and characterization of a novel immunomodulatory alpha-glucan-protein complex from the mycelium of Tricholoma matsutake in basidiomycetes. J Agric Food Chem 53: 8948-8956.

18. Standish LJ, Wenner CA, Sweet ES, Bridge C, Nelson A, et al. (2008) Trametes versicolor mushroom immune therapy in breast cancer. J Soc Integr Oncol 6: 122-128.

19. Novaes MRCG, Valadares F, Reis MC, Gonçalves DR, Eezes MDC (2011) The effects of dietary supplementation with Agaricales mushrooms and other medicinal fungi on breast cancer: Evidence-based medicine. Clinics 66: 2133-2139.

20. Chen W, Zhao Z, Chen SF, Li YQ (2008) Optimization for the production of exopolysaccharide from Fomes fomentarius in submerged culture and its antitumor effect in vitro. Bioresour Technol 99: 3187-3194.

21. Torkelson CJ, Sweet E, Martzen MR, Sasagawa M, Wenner CA, et al. (2012) Phase 1 Clinical Trial of Trametes versicolor in Women with Breast Cancer. ISRN Oncol 2012: 251632.

22. Bobek P, Ginter E, Jurcovicová M, Kuniak L (1991) Cholesterol-lowering effect of the mushroom Pleurotus ostreatus in hereditary hypercholesterolemic rats. Ann Nutr Metab 35: 191-195.

23. Cheung PCK (1996) The hypocholesterolemic effect of two edible mushrooms: Auricularia (tree-ear) and Tremella fuciformis (white jellyleaf) in hyper cholesterolemic rats. Nutrition Research 16: 1721-1725.

24. Cheung PCK (1996) Dietary fiber content and composition of some cultivated edible mushrooms fruiting bodies and mycelia. J Agric food chem 44: 468-471.
25. Cheung PCK (1996) The hypocholesterolemic effect of extracellular polysaccharide from submerged fermentation of mushroom. Nutrition Research 16: 1953-1957.

26. Cheug PCK, Tsui LM (1995) Hypocholesterolemic effect of edible fungi in rats. Sun Yatsen Journal University, 3: 229-231.

27. Yilmaz N, Solmaz M, Türkekul I, Elmastas M (2006) Fatty acid composition in some wild edible mushrooms growing in the middle Black Sea region of Turkey. Food Chemistry 99: 168-174.

28. Brown JE (2005) A critical review of methods used to estimate Linoleic acid? 6-desaturation ex vivo and in vivo. European Journal of Lipid Science and Technology 107: 119-134.

29. O'Fallon JV, Busboom JR, Nelson ML, Gaskins CT (2007) A direct method for fatty acid methyl ester synthesis: application to wet meat tissues, oils, and feedstuffs. See comment in PubMed Commons below J Anim Sci 85: 1511-1521.

30. Grundy SM (1994) Influence of stearic acid on cholesterol metabolism relative to other long-chain fatty acids. Am J Clin Nutr 60: 986S-990S.

31. Whetsell MS, Rayburn EB, Lozier JD (2003) Human Health Effects of Fatty Acids in Beef, Pasture-Based Beef Systems for Appalachia" project, a multi-institutional collaboration among West Virginia University.

32. Holtz RB, Schisler LC (1971) Lipid metabolism of Agaricus bisporus (Lange) sing.I. Analysis of sporephore and mycelia lipids. Lipids 7: 176-180.

33. Byrne PF, Brennan PJ (1975) The lipids of Agaricus bisporus. J Gen Microbiol 89: 245-255.

34. Stancher B, Procida G, Calabrese M (1992) Characteristics of the most common mushrooms cultivated in Italy. IV.Lipids: Determination of the content of free and bound fatty acids. Industrie Alimentari 31: 744-750.

35. Abdullah MI, Young JC, Games DE (1994) Supercritical fluid extraction of carboxylic and fatty acids from Agaricus Spp. Mushrooms. J Agric Food Chem 42: 718-722.

36. Karine Pedneault, Paul Angers, André Gosselin, Russell J Tweddell (2006) Fatty acid composition of lipids from mushrooms belonging to the family Boletaceae. Mycol Res 110: 1179-1183.

37. Pedneault, K., Angers, P., Gosselin, A., \& Tweddell, R. J. (2006). Fatty acid composition of lipids from mushrooms belonging to the family Boletaceae. Mycological research, 110: 1179-1183.

38. Holtz RB, Stewart PS, Patton S (1972) Isolation and characterization of membranes from the cultivated mushroom. Plant Physiol 50: 541-546.

39. Combet E, Henderson J, Eastwood DC, Burton KS (2009) Influence of sporophore development,damage,storage,and tissue specificity on the enzymic formation of volatiles in mushrooms (Agaricus bisporus). J Agric Food Chem 57: 3709-3717.

40. Barros L, Baptista P, Correia DM, Casal S, Oliveria B, et al. (2007) Fatty acid and sugar compositions and nutritional value of five wild edible mushrooms from Northeast Portugal. Food Chemistry 105: 140-145.

41. Longvah T, Deosthale YG (1998) Compositional and nutritional studies on edible wild mushroom from northeast India. Food Chemistry 65 331-334.

42. Kavishree S, Hemayathy J, Lokesh BR, Shashirekha MN, Rajarathnam S (2008) Fat and fatty acids of Indian edible mushrooms. Food Chemistry 106: 597-602.

43. Erwin JA (1973) Comparative biochemistry of fatty acids in eukaryotic microorganisms. In: Erwin JA(ed), Lipids and Biomembranes of Eukaryotic Microorganisms. Academic Press, New York 41: 143.

44. Sajbidor J (1997) Effect of some environmental factors on the content and composition of microbial membrane lipids. Crit Rev Biotechnol 17: 87-103.

45. Denich TJ, Beaudette LA, Lee H, Trevors JT (2003) Effect of selected environmental and physic-chemical factors on bacterial cytoplasmatic membranes. J Microbiol Methods 52: 149.

46. Mrozik A, Piotrowska-Seget Z, Labuzek S (2004) Cytoplasmatic bacterial membrane responses to environmental perturbations. Polish Journal of Environmental Studies 13: 487-494. 
Citation: Abugri DA, McElhenney WH, Willian KR (2016) Fatty Acid Profiling in Selected Cultivated Edible and Wild Medicinal Mushrooms in Southern United States. J Exp Food Chem 2: 108. doi:10.4172/2472-0542.1000108

Page 7 of 7

47. Kris-Etherton PM, Harris WS, Appel LJ; American Heart Association Nutrition Committee. (2002) Fish consumption, fish oil, omega-3 fatty acids, and cardiovascular disease. Circulation 106: 2747-2757.

48. Moshfegh A, Goldman J, Cleveland L (2005) What We Eat in America, NHANES 2001-2002 Usual Nutrient Intakes from Food Compared to Dietary Reference Intakes: US Department of Agriculture, Agricultural Research Service.

49. Masters C (1996) Omega-3 fatty acids and the peroxisome. Mol Cell Biochem 165: 83-93.

50. Simopoulos AP, Leaf A, Salem NJR (1999) Workshop on the essentiality of and recommended Dietary Intakes for Omega -6 and Omega-3 Fatty Acids. Journal of the American College of Nutrition 18: 487-489.

51. Simopoulos AP (2002) The importance of the ratio of omega-6/omega-3 essential fatty acids. Biomed Pharmacother 56: 365-379.

52. Murcia MA, Martínez-Tomé M, Vera A, Morte A, Gutierrez A et al. (2003) Effect of industrial processing on desert truffles Terfezia claveryi chatin and Picoa juniper Vittadini): proximate composition and fatty acids. Journal of Science Food and Agriculture 83: 535-541.

53. Frostegard A, Tunlid A, Baath E (1993) Phospholipid fatty acid composition, biomass, activity of microbial communities from two types experimentally exposed to different heavy metals. Applied and Environmental Microbiology 59: 3605-3617.
54. Frostegard A, Tunlid A, Baath E (1996) Changes in microbial community structure during long-term incubation in two soils experimentally contaminated with metals. Soil Biology and Biochemistry 28: 55-63.

55. Stahl PD, Klug MJ (1996) Characterization and differentiation of filamentous fungi based on Fatty Acid composition. Appl Environ Microbiol 62: 4136-4146.

56. Olsson PA (1999) Signature fatty acids provide tools for determination of the distribution and intereactions of mycorrhizal fungi in soil. FEMS Microbiology and Ecology 29: 303-310.

57. Olsson PA, Baath E, Jakobsen I, Soderstrom B (1995) The use of phospholipid and neutral lipid fatty acid to estimate biomass of arbuscular mycorrhizal mycelium in soil. Mycological Research 99: 623-629.

58. Dimou DM, Georgala A, Komaitis M, Aggelis G (2002) Mycelial fatty acid composition of Pleurotus spp. and its application in the intrageneric differentiatiation. Mycological Research 106: 925-929.

59. Bagci E, Bruehl L, Aitzetmüller K, Altan Y (2003) A chemotaxonomic approach to the fatty acid and tocochromanol content of Cannabis sativa L. (Cannabaceae). Turk J Bot 27: 141-147.

60. Wells GB, Dickson RC, Ester LR (1996) Isolation and composition of inositolphosphorylceramide-type sphingolipids of hyphal forms of Candida albicans. J Bacteriol 178: 6223-6226. 